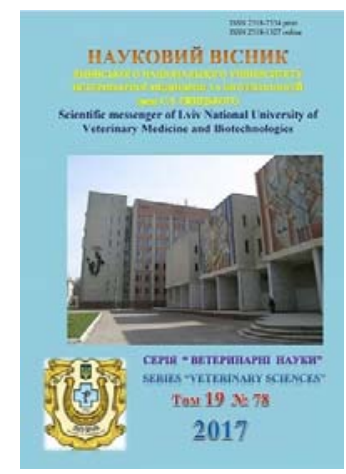

Науковий вісник Львівського національного університету ветеринарної медицини та біотехнологій імені С.З. Гжицького

Scientific Messenger of Lviv National University of Veterinary Medicine and Biotechnologies

doi:10.15421/nvlvet7816

ISSN 2518-7554 print

ISSN 2518-1327 online

$\underline{\text { http://nvlvet.com.ua/ }}$

УДК 636.2.09:591.48:591.11/.133.16

\title{
Зміни в вітамінній ланці антиоксидантної системи корів різних типів вищої нервової діяльності
}

\author{
Ю.О. Сисюк, В.І. Карповський, О.В. Журенко, О.В. Данчук, Р.В. Постой \\ karpovskiy@meta.ua
}

Національний університет біоресурсів і природокористування України, вул. Героїв Оборони, 11, м. Київ, 03041, Україна

\begin{abstract}
В статті наведено результати дослідження вмісту окремих вітамінів в сироватиі крові корів різних типів вищої нервової діяльності в залежності від пори року. Вміст аскорбінової кислоти в сироватиі крові корів різних типів ВНД в холодну пору року був нижчий відповідно на 22-27\% відповідно до показників тварин літом. Вміст жиророзчинних вітамінів у сироватчі крові корів різних типів ВНД у більщій мірі залежний від пори року. Так, вміст ретинолу та токоферолу був нижчий в холодну пору року у порівнянні із показником тварин літом на 35,8-55,3\% (P < 0,001) залежно від типу ВНД. Незалежно від пори року у тварин сильних типів ВНД вміст вітамінів в сироватиі крові достовірно не відрізняється, однак, встановлена тенденція щцодо вищого їх вмісту у сироватиі крові тварин СВР типу ВНД вищий вміст даних вітамінів 6 сироватиі крові ніж у тварин інших типів. У тварин слабкого типу ВНД вміст аскорбінової кислоти, токоферолу та ретинолу нижче від показників СВР типу ВНД на 13,2-14,4\% $(P<0,05)$.
\end{abstract}

Ключові слова: вища нервова діяльність, велика рогата худоба, ретинол, токоферол, аскорбінова кислота, пора року.

\section{Изменения в витаминном звене антиоксидантной системы коров разных типов высшей нервной деятельности}

\author{
Ю.А. Сисюк, В.И. Карповский, О.В. Журенко, О.В. Данчук, Р.В. Постой \\ karpovskiy@meta.ua
}

Наииональный университет биоресурсов и природопользования Украины, ул. Героев Обороны, 11, Киев, 03041, Украина

\begin{abstract}
В статье приведены результаты исследования содержания отдельных витаминов в сыворотке крови коров разных типов высшей нервной деятельности в зависимости от времени года. Содержание аскорбиновой кислоты в сыворотке крови коров разных типов ВНД в холодное время года был ниже соответственно на 22-27\% в соответствии с показателями животных летом. Содержание жирорастворимых витаминов в сыворотке крови коров разных типов ВНД в большей степени зависим от времени года. Так, содержание ретинола и токоферола было ниже в холодное время года по сравнению с показателем животных летом на 35,8-55,3\% (P <0,001) в зависимости от типа ВНД. Независимо от времени года у животных сильных типов ВНД содержание витаминов в сыворотке крови достоверно не отличается, однако, установлена тендениия высшего их содержания в сыворотке крови животных СВР типа ВНД выше содержание данных витаминов в сыворотке крови чем у животных других типов. У животных слабого типа ВНД содержание аскорбиновой кислоты, токоферола и ретинола ниже показателей СВР типа ВНД на 13,2-14,4\% (P<0,05).

Ключевые слова: высшей нервной деятельности, крупный рогатый скот, ретинол, токоферол, аскорбиновая кислота,
\end{abstract} время года.

Citation:

Sysyuk, Yu.O., Karpovskiy, V.I., Zhurenko, O.V., Danchuk, O.V., Postoy, R.V. (2017). Changes in the vitamin link of the antioxidant system in cows of different types of higher nervous activity. Scientific Messenger LNUVMB, 19(78), 81-85. 


\title{
Changes in the vitamin link of the antioxidant system in cows of different types of higher nervous activity
}

\author{
Yu.O. Sysyuk, V.I. Karpovskiy, O.V. Zhurenko, O.V. Danchuk, R.V. Postoy \\ karpovskiy@meta.ua
}

National University of Life and Environmental Sciences of Ukraine, Heroyiv Oborony Str., 11, Kyiv, 03041, Ukraine

\begin{abstract}
The article presents the results of the studying the content of some vitamins in blood serum of cows with different types of higher nervous activity depending on the season. The purpose of the study was to determine the influence of the typological features of the nervous system on the content of separate vitamins in blood serum of cows depending on the season.

The experiment was carried out on the basis of the farm "Kolos» village Borodianka, Kyiv region on clinically healthy cows of Ukrainian black-and-white dairy breed of 2-3 $3^{\text {rd }}$ lactation. On the basis of the investigation the conditioned reflex activity, 4 experimental groups of animals were formed with 4 most typical representatives of the identified types of higher nervous activity in each: $1^{\text {st }}$ group - strong balanced mobile type, $2^{\text {nd }}$ group - strong balanced inert type, $3^{\text {rd }}$ group - strong unbalanced type, $4^{\text {th }}$ group weak type. The research material was blood serum, in which the content of vitamins $A, E$ and $C$ was determined by express method via liquid chromatography. The conducted investigation of ascorbic acid, retinol and tocopherol content in blood serum of cows with different types of higher nervous activity in winter and summer periods shown that its content is significantly dependent on the season. In particular, the content of ascorbic acid in blood serum of cows with different types of higher nervous activity in the winter season was lower by 22-27\% in compare with its meaning in the summer season. It should be noted that the largest difference in content of vitamin $C$ in blood serum depending on the season was found in animals of strong balanced inert and weak types of higher nervous activity (by 27.4\%, $P<0.001$ and $24.0 \%, P<0.001$ respectively). While in animals of strong balanced mobile and strong unbalanced types of higher nervous activity the content of vitamin $C$ in blood serum was lower by $23.2 \%(P<0.001)$ and $21.7 \%(P$ $<0.001)$, respectively. The content of fat-soluble vitamins in blood serum of cows with different types of higher nervous activity is also largely dependent on the season. Thus, the content of tocopherol was lower in the winter season by 35.8-41.6\% (P<0.001) depending on the type of higher nervous activity. And the retinol content was lower by $49.2-55.3 \%(P<0.001)$.

Regardless of the season, there is no significant difference in vitamin content in blood serum between animals with strong types of higher nervous activity, however, there is a tendency of its higher content in blood serum of animals with strong balanced mobile type than in animals of other types. In animals of weak type of higher nervous activity, the content of ascorbic acid, tocopherol and retinol in blood serum is lower than in animals of strong balanced mobile type by $13.2-14.4 \%(P<0.05)$.

Significant influence of type of higher nervous activity on the content of ascorbic acid was found $-F=6.5>F U=3.0 ; P<0.01$, and tocopherol $-F=4.05>F U=3.0 ; P<0.05$. However, the main properties of cortical processes did not have a significant influence on the content of retinol in blood serum $-F=2.8<F U=3.0 ; P=0.06$. The season has a significant influence on the content of the above mentioned vitamins $-F=126-348>F U=4.3 ; P<0.001$, which is obviously due to the level of supply the animal's body with vitamins during different seasons. It should be noted that there is no relationship between the sources of variation (type of higher nervous activity and season), which obviously testifies to the absence of influence of the seasons on the main features of cortical processes $(F=0.37-1.64<F U=3.0 ; P=0.208-0.775)$.

Thus, the influence of the main features of cortical processes on the content of ascorbic acid, retinol and tocopherol in blood serum of cows is found. In animals of weak type of higher nervous activity the vitamin content in blood serum is lower than in animals of strong types. The lower content of ascorbic acid, retinol and tocopherol in blood serum of cows in the winter season, regardless the type of higher nervous activity, has been established.
\end{abstract}

Key words: higher nervous activity, cows, retinol, tocopherol, ascorbic acid, season.

\section{Вступ}

Тип нервової системи суттєво впливає на життєдіяльність цілісного організму, функціонування органів і систем, визначаючи індивідуальні відмінності тварин (Karpovskyi et al., 2016). Умовно-рефлекторна діяльність тварин залежить від індивідуальних властивостей нервової системи тварин, особливостей нервових процесів (Karpovskyi, 2011). Сила, врівноваженість та рухливість процесів збудження та гальмування в корі великого мозку є тими якостями, що забезпечують тварині максимально швидке і точне пристосування до мінливих умов зовнішнього середовища (Landarenko, 2016). Недостатність будь-якої 3 цих якостей негативно впливає на процес адаптації організму тварини (Danchuk et al., 2016). Встановлено, що тварини з високими показниками сили, врівноваженості та рухливості коркових процесів характеризуються високими господарсько-корисними (Kryvoruchko, 2013; Karpovskij et al., 2016), продуктивними якостя- ми та адаптаційними можливостями (Kobysh, 2005; Karpovskyi, 2015). Вони більш стійкі до впливу стресових чинників довкілля, тобто здатні більш повноцінно реалізувати свій генетичний потенціал (Danchuk et al., 2016). Слабкість нервових процесів і їх неврівноваженість роблять тварин менш пристосованими до умов середовища, що проявляється у зниженні їх резистентності та продуктивності (Danchuk et al., 2004).

Зростання інтенсивності виробництва продукції тваринництва супроводжується збільшенням впливу технологічного та біологічного навантаження на тварин, що супроводжується розвитком стресу (Karpovskyi, 2016; Martyshuk et al., 2016; Hariv and Gutyj, 2016). Розвиток стресу у організмі тварин супроводжується інтенсифікацією процесів пероксидного окиснення ліпідів, що, крім іншого, супроводжується пошкодженням ультраструктури плазматичних мембран і може призвести до загибелі клітини і проявляється розвитком системних порушень (Danchuk 
et al., 2004; Khariv et al., 2016; Gutyj et al., 2016; Khariv and Gutyj, 2017). Система антиоксидантного захисту у організмі тварин контролює всі етапи вільнорадикальних реакцій (Danchuk, 2014; Danchuk et al., 2016; Lavryshyn et al., 2016). III неферментативна ланка включає в себе цілий ряд жиророзчинних та водорозчинних сполук (Skrypkina, et al., 2016), основними 3 яких є вітаміни $\mathrm{A}, \mathrm{E}$ та С. Сучасними дослідженнями встановлено, що жиророзчинні вітаміни, особливо ретинол та токоферол, беруть участь у стабілізації біологічних мембран і захищають від окисного руйнування, а аскорбінова кислота активно зв'язує вільні радикали як у клітинах, так і у позаклітинному просTopi (Danchuk et al., 2004; Karpovskyi, 2015; Danchuk et al., 2016).

Мета дослідження - встановити вплив типологічних особливостей нервової системи на вміст окремих вітамінів в сироватці крові корів, залежно від пори року.

\section{Матеріал і методи дослідження}

Дослідження проводили на базі господарства ПСП «Колос» смт. Бородянка, Київської обл. на клінічно здорових коровах української чорно-рябої породи 2 3-ї лактації. Умови використання, утримання, раціон та кратність годівлі для всіх тварин були однаковими. Першим етапом досліджень було визначення типів ВНД за модифікованою методикою харчових умовних рефлексів, суть якої полягає в оцінці рухової реакції тварини до місця підкріплення кормом, швидкості вироблення та переробки умовного рухово-харчового рефлексу, ступеня орієнтувальної реакції та зовнішнього гальмування (Azariev et al., 2006). Прояв реакції тварин оцінювали в умовних одиницях (у.о.) від 1 до 4. На основі проведених досліджень умовнорефлекторної діяльності було сформовано 4 дослідні групи тварин по 4 найтиповіших представники визначених типів ВНД у кожній: І група - сильний врівноважений рухливий тип (CBP), II група - сильний врівноважений інертний тип (CBI), III група - сильний неврівноважений тип (CH), IV група - слабкий тип (C). Протягом наступного етапу були відібрані зразки крові у всіх піддослідних тварин. Відбір крові проводили двічі, улітку і зимою. Матеріалом для досліджень була сироватка крові, в якій визначали вміст вітамінів А, Е та С експрес - методом шляхом рідинної хроматографії (Vlizlo, 2012). Результати досліджень обробляли згідно із загальновизнаними методами статистики з використанням комп'ютерних програм Microsoft Exel.

\section{Результати та їх обговорення}

Проведені дослідження вмісту аскорбінової кислоти, ретинолу та токоферолу в сироватці крові різних типів вищої нервової діяльності від пори року свідчать про значну залежність їх вмісту від пори року. Зокрема, вміст аскорбінової кислоти в сироватці крові корів різних типів ВНД в холодну пору року був нижчий відповідно на 22-27\% відповідно до показників тварин літом (рис. 1). Слід відмітити, що найбільшу різницю встановлено у тварин СВI та слабкого типу ВНД (відповідно нижче на 27,4\%; Р < 0,001 та 24,0\%; $\mathrm{P}<0,001)$, тоді, як у тварин $\mathrm{CBP}$ та $\mathrm{CH}$ типу ВНД вміст вітаміну С в сироватці крові був нижче відповідно на 23,2\% (P < 0,001) та 21,7\% (P < 0,001). Вміст жиророзчинних вітамінів у сироватці крові корів різних типів ВНД у більшій мірі залежний від пори року (табл. 1). Так, вміст токоферолу також був нижчий в холодну пору року на $35,8-41,6 \%$ (P < 0,001) залежно від типу ВНД. А вміст ретинолу був нижче на 49,2$55,3 \%(\mathrm{P}<0,001)$.

Не залежно від пори року у тварин сильних типів ВНД вміст вітамінів в сироватці крові достовірно не відрізняється, однак, встановлена тенденція щодо вищого їх вмісту у сироватці крові тварин СВР типу ВНД вищий вміст даних вітамінів в сироватці крові ніж у тварин інших типів. У тварин слабкого типу ВНД вміст аскорбінової кислоти, токоферолу та ретинолу нижче від показників СВР типу ВНД на 13,2$14,4 \%(\mathrm{P}<0,05)$.

Багатофакторний дисперсійний аналіз вмісту окремих вітамінів у сироватці крові корів різних типів ВНД залежно від пори року наведений у табл. 2.

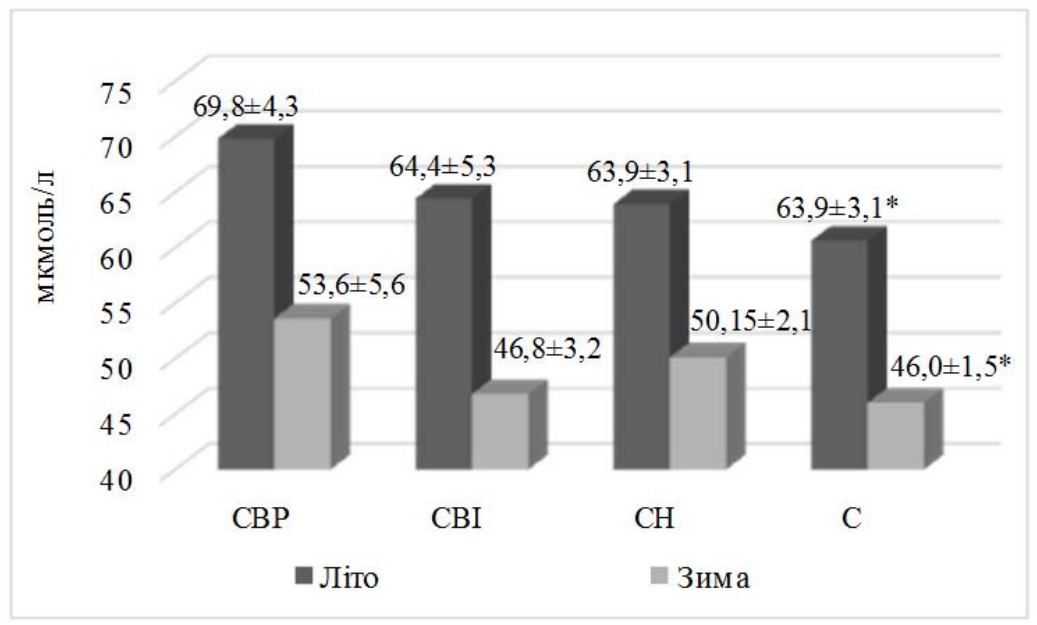

Рис. 1. Вміст аскорбінової кислоти в сироватці крові корів різних типів ВНД залежно від пори року (мкмоль/л; $\mathbf{M} \pm \mathbf{m}, \mathbf{n}=\mathbf{5}$ ) 
Табличя 1

Вміст жиророзчинних вітамінів в сироватці крові корів різних типів ВНД залежно від пори року (мкмоль/л; $\mathbf{M} \pm \mathbf{m}, \mathbf{n}=\mathbf{5}$ )

\begin{tabular}{|c|c|c|c|c|}
\hline \multirow{2}{*}{ Показники } & \multicolumn{4}{|c|}{ Тип ВНД } \\
\hline & CBP & $\mathrm{CBI}$ & $\mathrm{CH}$ & $\mathrm{C}$ \\
\hline \multicolumn{5}{|c|}{ Літо } \\
\hline Ретинол & $4,15 \pm 0,34$ & $3,93 \pm 0,35$ & $3,80 \pm 0,32$ & $3,58 \pm 0,34^{*}$ \\
\hline Токоферол & $21,55 \pm 2,05$ & $20,13 \pm 1,54$ & $19,25 \pm 1,01$ & $18,45 \pm 0,93^{*}$ \\
\hline \multicolumn{5}{|c|}{ Зима } \\
\hline Ретинол & $1,90 \pm 0,39$ & $1,85 \pm 0,24$ & $1,93 \pm 0,19$ & $1,60 \pm 0,26$ \\
\hline Токоферол & $12,58 \pm 0,76$ & $12,55 \pm 0,74$ & $12,25 \pm 0,78$ & $11,85 \pm 0,60$ \\
\hline
\end{tabular}

Примітка. Вірогідні різниці з СВР типом ВНД: $\mathrm{P}<0,05$ - *

Таблиця 2

Багатофакторний дисперсійний аналіз вмісту окремих вітамінів у сироватці крові корів різних типів ВНД залежно від пори року

\begin{tabular}{|c|c|c|c|c|c|c|}
\hline Джерело варіації & $\mathrm{SS}$ & $\mathrm{df}$ & MS & $\mathrm{F}$ & Р-значення & F критичне \\
\hline \multicolumn{7}{|c|}{ Вміст аскорбінової кислоти } \\
\hline Тип ВНД & 300 & 3 & 100 & 6,50 & 0,002 & 3,01 \\
\hline Пора року & 1933 & 1 & 1933 & 126 & $5,06 \mathrm{E}-11$ & 4,26 \\
\hline Взаємозв'язок & 17 & 3 & 5,7 & 0,371 & 0,775 & 3,01 \\
\hline Внутрішня & 369 & 24 & 15,4 & & & \\
\hline Всього & 2619 & 31 & & & & \\
\hline \multicolumn{7}{|c|}{ Вміст ретинолу } \\
\hline Тип ВНД & 0,806 & 3 & 0,269 & 2,80 & 0,062 & 3,01 \\
\hline Пора року & 33,4 & 1 & 33,4 & 348 & $8,56 \mathrm{E}-16$ & 4,26 \\
\hline Взаємозв’язок & 0,153 & 3 & 0,05 & 0,533 & 0,664 & 3,01 \\
\hline Внутрішня & 2,30 & 24 & 0,096 & & & \\
\hline Всього & 36,7 & 31 & & & & \\
\hline \multicolumn{7}{|c|}{ Вміст токоферолу } \\
\hline Тип ВНД & 16,0 & 3 & 5,35 & 4,05 & 0,018 & 3,01 \\
\hline Пора року & 455 & 1 & 454 & 345 & $9,65 \mathrm{E}-16$ & 4,26 \\
\hline Взаємозв’язок & 6,47 & 3 & 2,16 & 1,64 & 0,208 & 3,01 \\
\hline Внутрішня & 31,7 & 24 & 1,32 & & & \\
\hline Всього & 509 & 31 & & & & \\
\hline
\end{tabular}

Встановлено достовірний вплив типу ВНД на вміст аскорбінової кислоти $-\mathrm{F}=6,5>\mathrm{FU}=3,0$; $\mathrm{P}<0,01$, та токоферолу $-\mathrm{F}=4,05>\mathrm{FU}=3,0 ; \mathrm{P}<0,05$. Однак, основні характеристики коркових процесів не чинили достовірний вплив на вміст ретинолу в сироватці крові $-\mathrm{F}=2,8<\mathrm{FU}=3,0 ; \mathrm{p}=0,06$. Пора року має значний вплив на вміст вищевказаних вітамінів $\mathrm{F}=126-348>\mathrm{FU}=4,3 ; \mathrm{P}<0,001$, що очевидно пов'язано із рівним рівнем забезпеченості вітамінами організму тварин у різні пори року. Слід відмітити відсутність взаємозв'язку між джерелами варіації (типом ВНД та порою року), що очевидно засвідчує відсутність впливу пори року на основні характеристики коркових процесів $(\mathrm{F}=0,37-1,64<\mathrm{FU}=3,0 ; \mathrm{p}=$ 0,208-0,775).

\section{Висновки}

1. Встановлено вплив основних характеристик коркових процесів на вміст аскорбінової кислоти, ретинолу та токоферолу в сироватці крові корів. У сироватці крові тварини слабкого типу ВНД вміст вітамінів нижчий ніж у тварин сильних типів ВНД.
2. Встановлено нижчий вміст аскорбінової кислоти, ретинолу та токоферолу в сироватці крові корів у холодну пору року незалежно від типу вищої нервової діяльності.

\section{Бібліографічні посилання}

Karpovskyi, V.I., Zhurenko, O.V., Trokoz, V.O. (2016). Kortyko-vehetatyvni vzaiemyny v rehuliatsii fiziolohichnykh funktsii orhanizmu koriv. Naukovyi visnyk LNUVMBT imeni S.Z. Gzhytskoho. 18, 1(65), 65-69 (in Ukrainian).

Karpovskyi, V.I. (2011). Typy vyshchoi nervovoi diialnosti velykoi rohatoi khudoby ta kharakter adaptatsiinykh reaktsii na diiu zovnishnikh podraznykiv: avtoref. dys. ... dokt. vet. Nauk. NUBiP Ukrainy. K., 42 (in Ukrainian).

Khariv, M., Gutyj, B. (2017). Dynamika fagocytarnoi' aktyvnosti nejtrofiliv $u$ shhuriv za umov oksydacijnogo stresu ta dii' liposomal'nogo preparatu. The Animal Biology. 19(1), 119-124 (in Ukrainian). doi:10.15407/animbiol19.01.119 
Khariv, M., Gutyj, B., Butsyak, V., Khariv, I. (2016). Hematolohichni pokaznyky orhanizmu shchuriv za umov oksydatsiinoho stresu ta za dii liposomalnoho preparatu. Biological Bulletin of Bogdan Chmelnitskiy Melitopol State Pedagogical University. 6 (1), 276-289. doi: http://dx.doi.org/10.15421/ 201615 (in Ukrainian).

Landarenko, L.S. (2016). Osoblyvosti zhuinoho periodu v laktuiuchykh koriv $\mathrm{z}$ riznymy typolohichnymy osoblyvostiamy nervovoi diialnosti. Visnyk Sumskoho natsionalnoho ahrarnoho universytetu. Seriia: Veterynarna medytsyna. 11, 53-58 (in Ukrainian).

Lavryshyn, Y. Y., Varkholyak, I. S., Martyschuk, T. V., Guta, Z. A., Ivankiv, L. B., Paladischuk, O. R., Murska, S. D., Gutyj, B. V., \& Gufriy, D. F. (2016). The biological significance of the antioxidant defense system of animals body. Scientific Messenger LNUVMBT named after S.Z. Gzhytskyj. 18, 2(66), 100-111. doi:10.15421/nvlvet6622.

Danchuk, O.V., Karpovskyi, V.I., Danchuk, V.V. (2016). Indeksy intensyvnosti peroksydnoho okysnennia lipidiv u svynei za dii stresovoho faktora. Naukovyi visnyk LNUVMBT imeni S.Z. Gzhytskoho. 18, 1(65), 48-52 (in Ukrainian).

Karpovskij, V.I., Trokoz, V.A., Danchuk, A.V., Postoj, R.V., Karpovskij, V.V., Vasil'ev, A.P. (2016). Vlijanie osnovnyh korkovyh processov na produktivnost' svinej v period tehnologicheskogo stressa. Jekologija i zhivotnyj mir. 2, 8-13 (in Russian).

Kryvoruchko, D.I. (2013). Obmin rechovyn i produktyvnist koriv za riznoho tonusu avtonomnoi nervovoi systemy. Ahrarnyi visnyk Prychornomoria. Biolohichni nauky. 70, 78-83 (in Ukrainian).

Kobysh, A.I. (2005). Osoblyvosti proiaviv nespetsyfichnoi reaktyvnosti u koriv $\mathrm{v}$ zalezhnosti vid typiv vyshcho nervovoi diialnosti: dys. ... kandydata vet. nauk: 03.00.13. Kyiv, 144 (in Ukrainian).

Karpovskyi, P.V. (2015). Kortyko-vehetatyvna rehuliatsiia protsesiv nespetsyfichnoho imunitetu $\mathrm{V}$ orhanizmi svynei: dys. ... kandydata vet. nauk: 03.00.13. Kyiv, 193 (in Ukrainian).

Karpovskyi, V.V. (2016). Rol typiv vyshchoi nervovoi diialnosti $v$ rehuliatsii lipidnoho obminu svynei: dys. ... kandydata vet. nauk: 03.00.13. Kyiv, 182 (in Ukrainian).

Martyshuk, T. V., Gutyj, B. V., \& Vishchur, O. I. (2016). Riven produktiv perekysnoho okysnennia lipidiv u krovi shchuriv za umov oksydatsiinoho stresu ta za dii liposomalnoho preparatu «Butaselmevit». Biological Bulletin of Bogdan Chmelnitskiy Melitopol State Pedagogical University. 6 (2), 22-27. doi: http://dx.doi.org/10.15421/201631 (in Ukrainian).
Danchuk, V.V., Danchuk, O.V., Tsepko, N.L. (2004). Oksydatsiinyi stres - patolohiia chy adaptatsiia? Tvarynnytstvo Ukrainy. 4, 21-23 (in Ukrainian).

Danchuk, O.V. (2014). Indeks shyffoutvorennia u svynei riznykh typiv VND za dii tekhnolohichnykh streesiv. Naukovyi visnyk LNUVMBT imeni S.Z. Gzhytskoho. 16, 2(59), 89-92 (in Ukrainian).

Danchuk, O.V., Postoi, R.V., Karpovskyi, V.V., Kliutsuk, M.R., Skryhina, V.M., Karporvskyi, V.I., Zheltonozhska, T.B., Permiakova, N.M. (2016). Intensyvnist peroksydnoho okysnennia lipidiv $\mathrm{u}$ erytrotsytakh porosiat za dii mitseliarnoi formy tokoferolu. Naukovyi visnyk Natsionalnoho universytetu bioresursiv i pryrodokorystuvannia Ukrainy. Seriia: Veterynarna medytsyna, yakist i bezpeka produktsii tvarynnytstva. 237, 164-170 (in Ukrainian).

Gutyj, B.V., Hufriy, D.F., Hunchak, V.M., Khariv, I.I., Levkivska, N.D., Huberuk, V.O. (2016). The influence of metisevit and metifen on the intensity of lipid per oxidation in the blood of bulls on nitrate load. Scientific Messenger LNUVMBT named after S.Z. Gzhytskyj. 18, 3(70), 67-70. doi: http://dx.doi.org/10.15421/nvlvet7015.

Skrypkina, V.M., Karpovskyi, V.I., Postoi, R.V., Danchuk, O.V. (2016). Aktyvnist ta zbalansovanist fermentatyvnoi systemy anty-oksydantnoho zakhystu v orhanizmi svynei iz riznym tonusom avtonomnoi nervovoi systemy. Naukovyi visnyk Lvivskoho natsionalnoho universytetu veterynarnoi medytsyny ta biotekhnolohii im. S. Z. Gzhytskoho. 18, 1(65). 139144 (in Ukrainian).

Azariev, V.V., Karpovskyi, V.I., Trokoz, V.O., Kostenko, V.M., Kryvoruchko, D.I. (2006). Deklaratsiinyi patent Ukrainy na korysnu model № 16138. Sposib otsinky vlastyvostei nervovykh protsesiv u velykoi rohatoi khudoby. № u20060 2200; Zaiavl. 28.02.2006; Opubl. 17.07.2006. Biul. № 7 (in Ukrainian).

Hariv, M.I., Gutyj, B.V. (2016). Vplyv liposomalnoho preparatu Butaintervit na proteinsyntezuvalnu funktsiiu pechinky shchuriv za otruiennia tetrakhlormetanom [Influence of the liposomal preparation Butaintervite on protein synthesis function in the livers of rats under the influence of carbon tetrachloride poisoning]. Visnyk of Dnipropetrovsk University. Biology, medicine. 7(2), 123-126. doi: 10.15421/021622 (in Ukrainian).

Vlizlo, V.V. (2012). Laboratorni metody doslidzhennia u biolohii, tvarynnytstvi ta veterynarnii medytsyni: dovidnyk. Lviv: Spolom (in Ukrainian).

Received 21.09.2017

Received in revised form 5.10.2017 Accepted 10.10.2017 